\title{
HUBUNGAN KEPERCAYAAN DIRI DENGAN INTERAKSI SOSIAL ANAK USIA PRASEKOLAH DI TK RATNA KUMARA MEDAHAN
}

\author{
The Relationship of Self-Confidence with Social Interaction of Preschool Age \\ Children at Ratna Kumara Kindergarten, Medahan
}

\author{
Ni Komang Rosiana ${ }^{1}$, Ni Made Ari Sukmandari ${ }^{2}$, Claudia Wuri Prihandini ${ }^{3}$ \\ ${ }^{1}$ Program S1 Keperawatan, STIKES Bina Usada Bali, Indonesia \\ ${ }^{2}$ Program S1 Keperawatan, STIKES Bina Usada Bali, Indonesia \\ ${ }^{3}$ Program S1 Keperawatan, STIKES Bina Usada Bali, Indonesia
}

Korespondensi: Ni Made Ari Sukmandari dan arisukmandarimd@gmail.com

\begin{abstract}
ABSTRAK
Latar Belakang: Anak usia prasekolah adalah anak yang berumur 3-6 tahun yang memiliki periode optimal untuk mulai menunjukkan minat dalam kesehatan serta menunjukkan interaksi terhadap lingkungan sosial. Interaksi sosial merupakan suatu proses hubungan dinamis yang terjadi antara individu dengan individu, individu dengan kelompok, dan kelompok dengan kelompok sehingga menimbulkan hubungan timbal balik untuk mencapai tujuan masing-masing. Salah satu hal yang dapat membantu anak dalam interaksi sosial adalah dengan memiliki rasa kepercayaan diri. Kepercayaan diri merupakan keyakinan atas kemampuan yang dimiliki oleh individu untuk mencapai berbagai tujuan dalam hidupnya. Dengan memiliki rasa kepercayaan diri anak dapat mengetahui kekurangan dan kelebihan yang ada dalam diri anak, sehingga anak mampu menyelesaikan permasalahan yang dihadapi. Tujuan Penelitian: Tujuan penelitian ini adalah untuk mengetahui hubungan kepercayaan diri dengan interaksi sosial anak usia prasekolah di TK Ratna Kumara Medahan. Metedologi: Penelitian ini menggunakan metode penelitian jenis kuantitatif desain korelasional dengan pendekatan penelitian cross sectional. Sampel dalam penelitian ini adalah siswa siswi TK Ratna Kumara Medahan yang berjumlah 62 responden yang dipilih dengan metode simple random sampling. Uji analisia data yang digunakan adalah uji statistik non parametrik korelasi Spearman Rank. Hasil: Hasil penelitian ini menunjukkan 45 anak $(72,6 \%)$ memiliki kepercayaan diri yang tinggi dan 44 anak $(71,0 \%)$ memiliki kemampuan interaksi sosial yang baik. Berdasarkan hasil analisis data diperoleh hasil nilai $\mathrm{p}$-value $0,000<0,05$ yang berarti ada hubungan positif signifikan antara variabel kepercayaan diri dengan variabel interaksi sosial. Kesimpulan: Hasil penelitian ini diharapkan dapat menambah pengetahuan tentang perkembangan anak khususnya mengenai kepercayaan diri dan interaksi sosial pada anak.
\end{abstract}

Kata Kunci: Anak Usia Prasekolah; Interaksi Sosial; Kepercayaan Diri.

\section{ABSTRACT}

Background: Preschoolers are children aged 3-6 years who have an optimal period to start showing interest in health and showing interaction with the social environment. Social interaction is a dynamic relationship process that occurs between individuals and individuals, individuals with groups, and groups with groups, giving rise to reciprocal relationships to achieve their respective goals. One of the things that can help children in social interactions is to have a sense of self-confidence. Self-confidence 
is a belief in the ability possessed by individuals to achieve various goals in life. By having a sense of self-confidence, children can know the weaknesses and strengths that exist in them, so that children are able to solve the problems they face. Research Objectives: This study aimed to determine the correlation between self-esteem and social interaction of preschool children at Ratna Kumara Kindergarten, Medahan. Methodology: This study used a quantitative research method with a correlational design with a cross-sectional research approach. The sample in this study was Ratna Kumara Medahan Kindergarten students, numbering 62 respondents who were selected by simple random sampling method. The data analysis test used was a non-parametric statistical test of Spearman Rank correlation. Result: The results of this study showed 45 children (72.6\%) had high self-esteem and 44 children (71.0\%) had good social interaction skills. Based on the results of data analysis, the p-value of $0.000<0.05$, which means that there was a significant positive correlation between the self-esteem variable and the social interaction variable. Conclusions: The results of this study are expected to increase knowledge about child development, especially regarding selfesteem and social interaction in children.

Keywords: Preschool Age Children; Self-Confidence; Social Interaction.

\section{PENDAHULUAN}

Anak usia prasekolah adalah anak yang berumur 3-6 tahun dimana pada usia ini memiliki keingintahuan yang sangat tinggi atau disebut juga The Wonder Years. Anak usia prasekolah memiliki periode yang optimal untuk mulai menunjukkan minat dalam kesehatan serta menunjukkan interaksi terhadap lingkungan sosial (Mansur, 2019). Pada usia prasekolah anak berada pada tahap perkembangan psikososial inisiatif vs rasa bersalah. Pada tahap ini anak belajar berfantasi dan mulai belajar bahwa ada orang lain selain dirinya. Anak-anak mulai mengenal identitas dirinya dari jenis kelamin dan juga perlakuan sekitarnya. Pada tahap ini anak akan mulai melibatkan diri dalam berbagai aktifitas bersama dengan teman-temannya. Gangguan pada tahap perkembangan ini akan mengakibatkan anak menjadi kurang inisiatif, pasif, takut mecoba hal baru, dan terkadang mempunyai masalah dalam bergaul dengan teman-temannya (Ahyani \& Astuti, 2018).
Interaksi adalah suatu peristiwa saling memengaruhi satu sama lain ketika dua orang atau lebih hadir bersama dan terjalinnya komunikasi. Pada anak usia prasekolah tidak selamanya anak berhasil melakukan interaksi, ada kalanya anak kesulitan dalam berinteraksi sehingga anak gagal menyamakan standar dalam kelompoknya yang mengakibatkan anak menjadi korban kekerasan. Untuk dapat berinteraksi tentunya anak harus memiliki rasa percaya diri yang mana hal ini membantu anak dalam berinteraksi sosial. Kepercayaan diri merupakan keyakinan atas kemampuan diri sendiri yang dimiliki seseorang. Rasa percaya diri perlu dikembangkan sedini mungkin agar anak mampu melakukan penyesuain diri dengan lingkungannya. Dikatakan anak yang dapat bersosialisasi dan berinteraksi yang baik adalah anak yang memiliki kepercayaan diri yang baik juga (Rachmawati, 2015).

Diperkirakan sebanyak 20\% anak mengalami masalah hubungan dengan teman sebaya (Rahmadi et al., 2016). Di Jakarta sebanyak 54,81\% anak 
mengalami masalah terhadap hubungan dengan teman sebaya (Devita, 2019). Di Bali sebanyak $10 \%$ anak memiliki interaksi sosial yang kurang dan $37 \%$ anak memiliki interkasi sosial yang cukup Andarbeni (2013). Hasil penelitian Hidayatullah (2017) menunjukkan bahwa $62,5 \%$ anak memiliki interaksi sosial cukup dan $37,5 \%$ anak memiliki interaksi sosial baik. Sementara itu, berdasarkan hasil kajian mengenai kepercayaan diri yang merupakan suatu unsur dari interaksi sosial yang pernah didapat oleh Kementerian Pemerdayaan Perempuan dan Perlindungan Anak Republik Indonesia pada tahun 2018 sebanyak 56\% anak mengalami krisis kepercayaan diri (KPPPA, 2019). Di Bali sebanyak $72 \%$ persen anak memiliki kepercayaan diri sedang (Siyani et al., 2016). Hasil penelitian kepercayaan diri pada anak yang dilakukan oleh Ilya \& Fitriana (2020) adalah moyoritas anak memiliki kepercayaan diri rendah yaitu $41,3 \%$. Hasil dari penelitian yang dilakukan oleh Asih \& Astriyanti (2019) adalah 97,5\% anak memiliki kepercayaan diri rendah dan 2,5\% anak memiliki kepercayaan diri sedang.

\section{TUJUAN PENELITIAN}

Adapun Tujuan Umum pada penelitian ini adalah untuk mengetahui hubungan Hubungan Kepercayaan Diri dengan Interaksi Sosial Anak Usia Prasekolah di TK Ratna Kumara Medahan.

\section{METODE PENELITIAN}

Penelitian ini menggunakan metode penelitian jenis kuantitatif desain korelasional dengan pendekatan penelitian cross sectional. Sampel penelitian sebanyak 62 responden yang dipilih dengan metode simple random sampling. Populasi dalam penelitian ini adalah siswa - siswi TK Ratna Kumara tahun ajaran 2020/2021. Pengumpulan data dilakukan dengan menggunakan kuesioner kepercayaan diri dan kuesioner interaksi sosial dengan skala yang digunakan adalah skala model Likert yang mengunakan respon skala lima, yaitu sangat setuju (SS), setuju (S), ragu-ragu (R), tidak setuju (TS), dan sangat tidak setuju (STS). Instrument yang digunakan sudah melawati uji validitas dan reliabilitas. Penelitian ini telah lolos kaji etik melalui Komisi Etik Penelitian Kesehatan (KEPK) STIKES Bina Usada Bali. Analisis data menggunakan uji Spearman Rank.

\section{HASIL PENELITIAN}

Tabel 1. Gambaran Karakteristik

Subyek Penelitian Berdasarkan Usia

\begin{tabular}{llllll}
\hline Variabel & $\mathrm{N}$ & Rerata & Min & Maks & SD \\
\hline Usia & 62 & 5,66 & 5 & 6 & 0,477 \\
\hline
\end{tabular}

Tabel 1. menunjukkan rata- rata usia responden adalah 5,66 dengan usia tertinggi yaitu 6 tahun dan terendah 5 tahun.

Tabel 2. Gambaran Karakteristik Subyek Penelitian Berdasarkan Jenis Kelamin

\begin{tabular}{ccc}
\hline Kategori & Frekuensi & $\begin{array}{c}\text { Persentase } \\
\mathbf{( \% )}\end{array}$ \\
\hline Laki - laki & 32 & $51,6 \%$ \\
\hline Perempuan & 30 & $48,4 \%$ \\
\hline Total & 62 & $100 \%$ \\
\hline
\end{tabular}

Tabel 2. menunjukkan sebagian besar responden dengan jenis kelamin laki - laki yaitu sebanyak 32 responden $(51,6 \%)$. 
Tabel 3. Gambaran Karakteristik Subyek Penelitian Berdasarkan Tingkat Kepercayaan Diri

\begin{tabular}{ccc}
\hline Kategori & Frekuensi & Persentase (\%) \\
\hline Rendah & 0 & $0 \%$ \\
\hline Sedang & 17 & $27,4 \%$ \\
\hline Tinggi & 45 & $72,6 \%$ \\
\hline Total & 62 & $100 \%$ \\
\hline
\end{tabular}

Tabel 3. menunjukkan sebagian besar responden memiliki kepercayaan diri yang tinggi yaitu sebanyak 45 responden $(72,6 \%)$.
Tabel 4. Gambaran Karakteristik Subyek Penelitian Berdasarkan Tingkat Interaksi Sosial

\begin{tabular}{ccc}
\hline Kategori & Frekuensi & Persentase (\%) \\
\hline Kurang & 0 & $0 \%$ \\
\hline Cukup & 18 & $29,0 \%$ \\
\hline Baik & 44 & $71,0 \%$ \\
\hline Total & 62 & $100 \%$ \\
\hline
\end{tabular}

Tabel 4. menunjukkan sebagian besar responden memiliki tingkat interaksi sosial baik yaitu sebanyak 44 responden $(71,0 \%)$.

Tabel 5. Hasil Analisis Hubungan Kepercayaan Diri Dengan Interaksi Sosial Pada Anak Usia Prasekolah di TK Ratna Kumara Medahan

\begin{tabular}{|c|c|c|c|c|c|c|c|c|c|c|}
\hline \multirow{3}{*}{$\begin{array}{c}\text { Kepercayaan } \\
\text { Diri }\end{array}$} & \multicolumn{6}{|c|}{ Interaksi Sosial } & \multicolumn{2}{|c|}{ Total } & \multirow{2}{*}{$\begin{array}{c}\text { Correlation } \\
\text { Coefficient }\end{array}$} & \multirow[t]{2}{*}{ P-Value } \\
\hline & \multicolumn{2}{|c|}{ Kurang } & \multicolumn{2}{|c|}{ Cukup } & \multicolumn{2}{|c|}{ Baik } & & & & \\
\hline & $\mathrm{N}$ & $\%$ & $\mathrm{~N}$ & $\%$ & $\mathrm{~N}$ & $\%$ & $\mathrm{~N}$ & $\%$ & 0,531 & 0,000 \\
\hline Rendah & 0 & 0 & 0 & 0 & 0 & 0 & 0 & 0 & & \\
\hline Sedang & 0 & 0 & 13 & 21,0 & 4 & 6,5 & 17 & 27,4 & & \\
\hline Tinggi & 0 & 0 & 5 & 8,1 & 40 & 64,5 & 45 & 72,6 & & \\
\hline Total & 0 & 0 & 18 & 29,0 & 44 & 71,0 & 62 & 100,0 & & \\
\hline
\end{tabular}

Tabel 5. menunjukkan sebaian besar responden memiliki tingkat kepercayaan diri yang tinggi serta memiliki tingkat interaksi sosial yang baik yaitu sebanyak 40 responden $(64,5 \%)$. Berdasarkan hasil nilai $p$-value yaitu sebesar 0,000 yang berarti $\alpha<0,05$, ini menyatakan ada hubungan signifikan antara kepercayaan diri dengan interaksi sosial pada anak usia pra sekolah di TK RAtna Kumara Medahan. Hasil correlation coefficient didapat sebesar 0,531 yang menyatakan tingkat kekuatan hubungan antara variabel kepercayaan diri dengan interaksi sosial berada pada tingkat sedang. Angka correlation coefficient tersebut bernilai positif, sehingga hubungan kedua variabel tersebut bersifat searah.

\section{PEMBAHASAN}

Kemampuan individu mengadakan interaksi sosial sangat penting, karena dengan adanya interaksi sosial seseorang dapat mengetahui apakah dirinya diterima dengan baik atau ditolak dari lingkungan sosialnya. Interaksi sosial merupakan suatu proses hubungan dinamis yang terjadi antara individu dengan individu, individu dengan kelompok, dan kelompok dengan kelompok sehingga menimbulkan hubungan timbal balik untuk mencapai tujuan masing-masing. Interaksi sosial yang dilakukan anak di sekolah memiliki peranan yang penting berkaitan dengan proses penempatan dirinya diantara teman-teman ataupun guru-guru. Dalam mengadakan interaksi sosial anak harus memiliki rasa kepercayaan diri sebagaimana dikemukakan oleh Vallet 2001 (dalam Zahara, 2018) bahwa seseorang akan mampu dan berani 
menunjukkan eksistensinya apabila memiliki rasa percaya diri yang baik.

Kepercayaan diri merupakan modal utama bagi seseorang untuk mengembangkan dan mewujudkan potensi yang ada dalam dirinya. Memiliki rasa kepercayaan diri akan membuat seseorang untuk belajar dan bekerja keras demi mencapai kemajuan serta penuh keyakinan dalam menjalani perannya. Menurut Lauster 1978 (dalam Safitri, 2020) kepercayaan diri merupakan suatu sikap atau keyakinan atas kemampuan diri sendiri, sehingga individu dalam bertindak tidak terlalu cemas, merasa bebas melakukan hal-hal sesuai keinginan dan bertanggungjawab atas perbuatannya, sopan dalam berinteraksi dengan orang lain, serta dapat mengenal kelebihan dan kekurangan diri sendiri. Membentuk kepercayaan diri pada diri seseorang diawali dengan perkembangan konsep diri yang diperoleh dalam pergaulan suatu kelompok. Kemampuan mengelola kepercayaan diri dengan baik sangat penting terutama ketika seseorang barada dalam proses penyesuaian dengan lingkungan baru seperti halnya anak usia prasekolah yang baru memasuki lingkungan sekolah.

Pada penelitian ini anak yang memiliki kepercayaan diri yang tinggi, memiliki kemampuan interaksi sosial yang baik, sedangkan anak yang memiliki kepercayaan diri yang sedang, memiliki kemampuan interaksi yang cukup. Hal ini membuktikan bahwa tingkat kepercayaan diri memiliki hubungan dengan kemampuan interaksi sosial pada anak karena kepercayaan diri dapat membantu anak dalam menyesuikan diri dengan lingkungan sehingga dapat terjadi interaksi sosial dalam lingkungan tersebut.

\section{KESIMPULAN}

Hasil penelitian mengenai kemampuan interaksi sosial anak di TK Ratna Kumara Medahan berada pada kategori baik yaitu sebanyak $71,0 \%$ anak. Hasil penelitian tentang tingkat kepercayaan diri anak di TK Ratna Kumara Medahan berada pada kategori tinggi yaitu sebanyak $72,6 \%$ anak. Dari hasil analisis data didapatkan ada hubungan yang positif signifikan antara kepercayaan diri dengan interaksi sosial anak usia prasekolah di TK Ratna Kumara Medahan.

\section{DAFTAR PUSTAKA}

Ahyani, L. N., \& Astuti, R. D. (2018). Buku Ajar Psikologi Perkembangan Anak dan Remaja (Issue January 2019, p. 81).

Andarbeni, S. L. (2013). Studi Tentang Kemampuan Interaksi Sosial Anak Kelompok A dalam Kegiatan Metode Proyek di TK Plus Al-falah Pungging Mojokerto. Jurnal BK Unesa, 4(1), 285-292.

Asih, S., \& Astriyanti, S. (2019). Pola Asuh Orang Tua Meningkatkan Percaya Diri Pada Anak Prasekolah Di Tk Islam Terpadu Amanah Sumbersari Jember. Journal of Ners Community, 10(November), 243-250.

Devita, Y. (2019). Prevalensi Masalah Mental Emosional Remaja Di Kota Pekanbaru. Jurnal Keperawatan Priority, 2(1), 3343.

Hidayatullah, M. A. (2017). Hubungan Kebiasaan Bermain Gadget dengan Interaksi Sosial Anak Usia Prasekolah di KB-TK ArRahim Kecamatan Ungaran Timur Kabupaten Semarang. Universitas Ngudi Waluyo, 1-12.

Hotimah, A. K., \& Ukhwatun, N. (2015). Mengembangkan Kepercayaan 
Diri Anak Melalui Komunikasi Eksprensif pada Pembelajaran di Kelas Anak Usia Dini. Prosiding Seminar Nasional Pendidikan, November, 80-86.

Ilya, L. K., \& Fitriana, L. B. (2020). Pola Asuh Ibu Berhubungan dengan Kepercayaan Diri Anak di TK Kanisius Banguntapan Bantul Yogyakarta. Jurnal ILKES, 11(1), 195-206.

KPPPA. (2019). Profil Anak Indonesia Tahun 2019. In Kementerian Pemerdayaan Perempuan dan Perlindngan Anak (KPPPA). https://www.kemenpppa.go.id/lib /uploads/list/15242-profil-anakindonesia_-2019.pdf.

Mansur, A. R. (2019). Tumbuh Kembang Anak Usia Prasekolah (S. Hidayat \& I. Anwar (eds.); 1st ed., Issue December). Andalas Universty Press.

Nursalam. (2013). Ilmu Keperawatan Pendekatan Praktis. Yogyakarta : Salemba Medika.

Rachmawati. (2015). Hubungan Antara Interaksi Sosial dengan Kepercayaan Diri Dalam Public Speaking. In Skripsi (pp. 1-12).

Rahmadi, F. A., Hardaningsih, G., \& Pratiwi, R. (2016). Prevalensi dan jenis masalah emosional dan perilaku pada anak usia 9-11 tahun dengan perawakan pendek di Kabupaten Brebes. Jurnal Gizi Indonesia (The Indonesian Journal of Nutrition), 3(2), 116119. https://doi.org/10.14710/jgi.3.2.1 16-119.

Safitri, S. (2020). Hubungan Kepercayaan Diri dengan Interaksi Sosial pada Mahasiswa Semester III Prodi BImbingan dan Konseling Pendidikan Islam UIN Raden Intan Lampung Tahun Akademik 2019/2020. In
Skripsi (pp. 1-65)

Siyani, N. A., Asri, I. G. A. A. S., \& Putra, I. K. A. (2016). Penerapan Permainan Tradisional MeongMeong Untuk Meningkatkan Percaya Diri Anak Kelompok B3 Kumara Adi I Denpasar. Jurnal Pendidikan Anak Usia Dini Universitas Pendidikan Ganesha, 4(1), 1-10.

Siyoto, S., \& Sodik, A. (2015). Dasar Metodologi Penelitian. Jakarata : Media Publising.

Zahara, F. (2018). Hubungan Antara Kepercayaan Diri Dengan Interaksi Sosial Pada Mahasiswa Universitas Potensi Utama Medan. Kognisi Jurnal, 2(2), 7787. 